NASA/TM-2001-210395

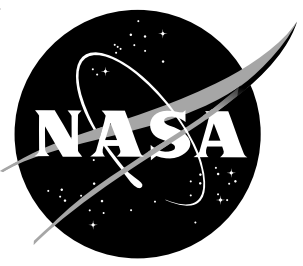

\title{
The F-15B Propulsion Flight Test Fixture: A New Flight Facility For Propulsion Research
}

Stephen Corda, M. Jake Vachon, Nathan Palumbo,

Corey Diebler, Ting Tseng, Anthony Ginn, and David Richwine

NASA Dryden Flight Research Center

Edwards, California 


\section{The NASA STI Program Office...in Profile}

Since its founding, NASA has been dedicated to the advancement of aeronautics and space science. The NASA Scientific and Technical Information (STI) Program Office plays a key part in helping NASA maintain this important role.

The NASA STI Program Office is operated by Langley Research Center, the lead center for NASA's scientific and technical information. The NASA STI Program Office provides access to the NASA STI Database, the largest collection of aeronautical and space science STI in the world. The Program Office is also NASA's institutional mechanism for disseminating the results of its research and development activities. These results are published by NASA in the NASA STI Report Series, which includes the following report types:

- TECHNICAL PUBLICATION. Reports of completed research or a major significant phase of research that present the results of NASA programs and include extensive data or theoretical analysis. Includes compilations of significant scientific and technical data and information deemed to be of continuing reference value. NASA's counterpart of peer-reviewed formal professional papers but has less stringent limitations on manuscript length and extent of graphic presentations.

- TECHNICAL MEMORANDUM. Scientific and technical findings that are preliminary or of specialized interest, e.g., quick release reports, working papers, and bibliographies that contain minimal annotation. Does not contain extensive analysis.

- CONTRACTOR REPORT. Scientific and technical findings by NASA-sponsored contractors and grantees.
- CONFERENCE PUBLICATION.

Collected papers from scientific and technical conferences, symposia, seminars, or other meetings sponsored or cosponsored by NASA.

- SPECIAL PUBLICATION. Scientific, technical, or historical information from NASA programs, projects, and mission, often concerned with subjects having substantial public interest.

- TECHNICAL TRANSLATION. Englishlanguage translations of foreign scientific and technical material pertinent to NASA's mission.

Specialized services that complement the STI Program Office's diverse offerings include creating custom thesauri, building customized databases, organizing and publishing research results...even providing videos.

For more information about the NASA STI Program Office, see the following:

- Access the NASA STI Program Home Page at http://www.sti.nasa.gov

- E-mail your question via the Internet to help@sti.nasa.gov

- Fax your question to the NASA Access Help Desk at (301) 621-0134

- Telephone the NASA Access Help Desk at (301) 621-0390

- Write to:

NASA Access Help Desk

NASA Center for AeroSpace Information 7121 Standard Drive

Hanover, MD 21076-1320 
NASA/TM-2001-210395

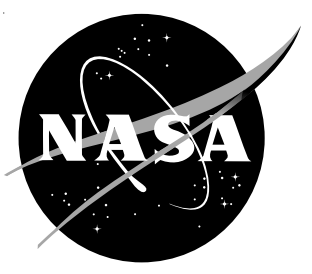

\section{The F-15B Propulsion Flight Test Fixture: A New Flight Facility For Propulsion Research}

Stephen Corda, M. Jake Vachon, Nathan Palumbo,

Corey Diebler, Ting Tseng, Anthony Ginn, and David Richwine

NASA Dryden Flight Research Center

Edwards, California

National Aeronautics and

Space Administration

Dryden Flight Research Center

Edwards, California 93523-0273 


\section{NOTICE}

Use of trade names or names of manufacturers in this document does not constitute an official endorsement of such products or manufacturers, either expressed or implied, by the National Aeronautics and Space Administration.

Available from the following:

NASA Center for AeroSpace Information (CASI)

7121 Standard Drive

Hanover, MD 21076-1320

(301) 621-0390
National Technical Information Service (NTIS) 5285 Port Royal Road Springfield, VA 22161-2171

(703) $487-4650$ 


\title{
THE F-15B PROPULSION FLIGHT TEST FIXTURE: A NEW FLIGHT FACILITY FOR PROPULSION RESEARCH
}

\author{
Stephen Corda, ${ }^{*}$ M. Jake Vachon,${ }^{\dagger}$ Nathan Palumbo, ${ }^{\ddagger}$ Corey Diebler,${ }^{\S}$ \\ Ting Tseng, ${ }^{\text {,I }}$ Anthony Ginn, ${ }^{\#}$ and David Richwine** \\ NASA Dryden Flight Research Center \\ Edwards, California
}

\begin{abstract}
$\underline{\text { ABSTRACT }}$
The design and development of the F-15B Propulsion Flight Test Fixture (PFTF), a new facility for propulsion flight research, is described. Mounted underneath an F-15B fuselage, the PFTF provides volume for experiment systems and attachment points for propulsion devices. A unique feature of the PFTF is the incorporation of a six-degree-of-freedom force balance. Three-axis forces and moments can be measured in flight for experiments mounted to the force balance. The NASA F-15B airplane is described, including its performance and capabilities as a research test bed aircraft. The detailed description of the PFTF includes the geometry, internal layout and volume, force-balance operation, available instrumentation, and allowable experiment size and weight. The aerodynamic, stability and control, and structural designs of the PFTF are discussed, including results from aerodynamic computational fluid dynamic calculations and structural analyses. Details of current and future propulsion flight experiments are discussed. Information about the integration of propulsion flight experiments is provided for the potential PFTF user.

*Chief, Propulsion and Performance Branch, AIAA Member $\dagger$ Aerospace Engineer, AIAA Member

\$Aerospace Engineer

$\S$ Aerospace Engineer

IfAerospace Engineer

\#Aerospace Engineer

**Aerospace Engineer

Copyright (C) 2001 by the American Institute of Aeronautics and Astronautics, Inc. No copyright is asserted in the United States under Title 17, U.S. Code. The U.S. Government has a royalty-free license to exercise all rights under the copyright claimed herein for Governmental purposes. All other rights are reserved by the copyright owner.
\end{abstract}

\section{NOMENCLATURE}

$\begin{array}{ll}C_{D} & \text { drag coefficient } \\ C_{l_{\beta}} & \quad \begin{array}{l}\text { dihedral effect derivative (rolling moment } \\ \text { caused by angle of sideslip) }\end{array} \\ C_{m_{\alpha}} & \begin{array}{l}\text { longitudinal static stability derivative } \\ C_{n_{\beta}}\end{array} \\ \begin{array}{l}\text { directional static stability derivative } \\ \text { ("weathercock" stability) }\end{array} \\ C_{Y} & \text { side force coefficient } \\ \text { CFD } & \text { computational fluid dynamics } \\ F & \text { force } \\ \text { F. S. } & \text { fuselage station } \\ \text { FTF-II } & \text { Flight Test Fixture II } \\ \text { GPS } & \text { global positioning system } \\ \text { PCM } & \text { pulse code modulation } \\ \text { PFTF } & \text { Propulsion Flight Test Fixture } \\ q & \text { dynamic pressure, lbf/ft }{ }^{2} \\ \text { RBCC } & \text { rocket-based combined cycle } \\ x & \text { axial direction } \\ y & \text { side direction } \\ z & \text { vertical direction } \\ \beta & \text { angle of sideslip, deg } \\ & \quad \text { INTRODUCTION }\end{array}$

In recent years, interest has been renewed in flight demonstrations of advanced air-breathing propulsion systems. Concepts such as the rocket-based combined cycle (RBCC) and pulse detonation engine (PDE) have come to the forefront of next-generation propulsion systems for missiles, high-speed aircraft, and space access. To take these and other propulsion concepts from ground test to a real flight environment, NASA Dryden 
Flight Research Center (Edwards, California) has developed the Propulsion Flight Test Fixture (PFTF) for the NASA F-15B research airplane (fig. 1).

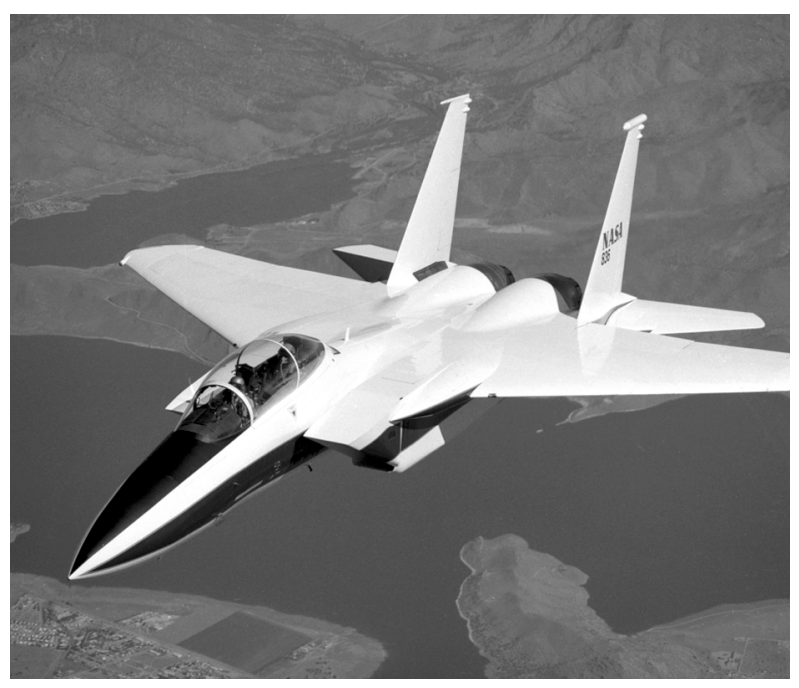

EC96-43546-1

Figure 1. The NASA F-15B airplane in flight.

The PFTF (fig. 2) builds on flight research experience with the NASA F-15B aerodynamic Flight Test Fixture II (FTF-II). ${ }^{1}$ The F-15B-PFTF combination provides a unique, low-cost flight facility for developing and flight-
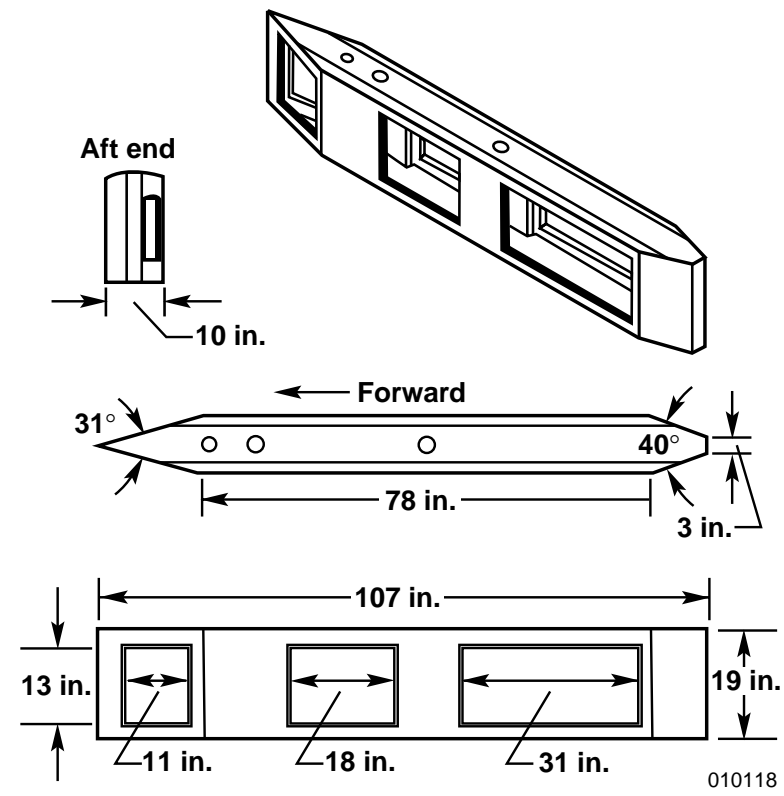

Figure 2. The PFTF. testing advanced propulsion systems and components. The PFTF is mounted along the fuselage centerline underneath the F-15B airplane. The fixture provides the support structure and volume for propellant feed systems, control systems, and instrumentation needed to flight-test propulsive devices. Subsonic, transonic, and supersonic flight data can be obtained for test points to a maximum speed of approximately Mach 1.8 and dynamic pressure of $1100 \mathrm{lbf} / \mathrm{ft}^{2}(52.67 \mathrm{kPa})$.

Note that use of trade names or names of manufacturers in this document does not constitute an official endorsement of such products or manufacturers, either expressed or implied, by the National Aeronautics and Space Administration.

\section{AIRPLANE AND AERODYNAMIC FLIGHT TEST FIXTURE II DESCRIPTION}

The F-15B aircraft is a two-seat fighter and trainer version of the F-15 high-performance, supersonic air-superiority fighter built by the McDonnell Aircraft Company (now The Boeing Company, St. Louis, Missouri). The aircraft is powered by two F100-PW-100 turbofan engines with afterburners manufactured by Pratt \& Whitney Aircraft Engines (West Palm Beach, Florida). Each engine has an uninstalled, sea-level static thrust rating of approximately 25,000 $\mathrm{lbf}(91,188 \mathrm{~N})$. The F-15B aircraft has a length of $63.7 \mathrm{ft}(19.42 \mathrm{~m})$ and a wingspan of $42.8 \mathrm{ft}$ (13.05 m) (fig. 3). The aircraft has a basic operating weight of $27,500 \mathrm{lb}(12,474 \mathrm{~kg})$ and a maximum takeoff gross weight of $54,000 \mathrm{lb}$ $(24,494 \mathrm{~kg})$.

The NASA F-15B airplane has been converted from its United States Air Force role as an air-superiority fighter to a research test bed airplane. Research instrumentation, recording, telemetry, and video systems have been installed in the airplane. One significant feature of the F-15B research capability is the ability to carry the aerodynamic FTF-II. The FTF-II is a lowaspect-ratio, fin-like shape installed on the F-15B centerline pylon similar to the installation of an operational centerline fuel tank (fig. 3). The FTF-II is a second-generation research fixture; the first flight test fixture was flown on the NASA F-104 airplane. ${ }^{1}$ The FTF-II has a length of $107 \mathrm{in} .(271.80 \mathrm{~cm})$, a height of 32 in. $(81.28 \mathrm{~cm})$, and a width of 8 in. $(20.32 \mathrm{~cm})$. 


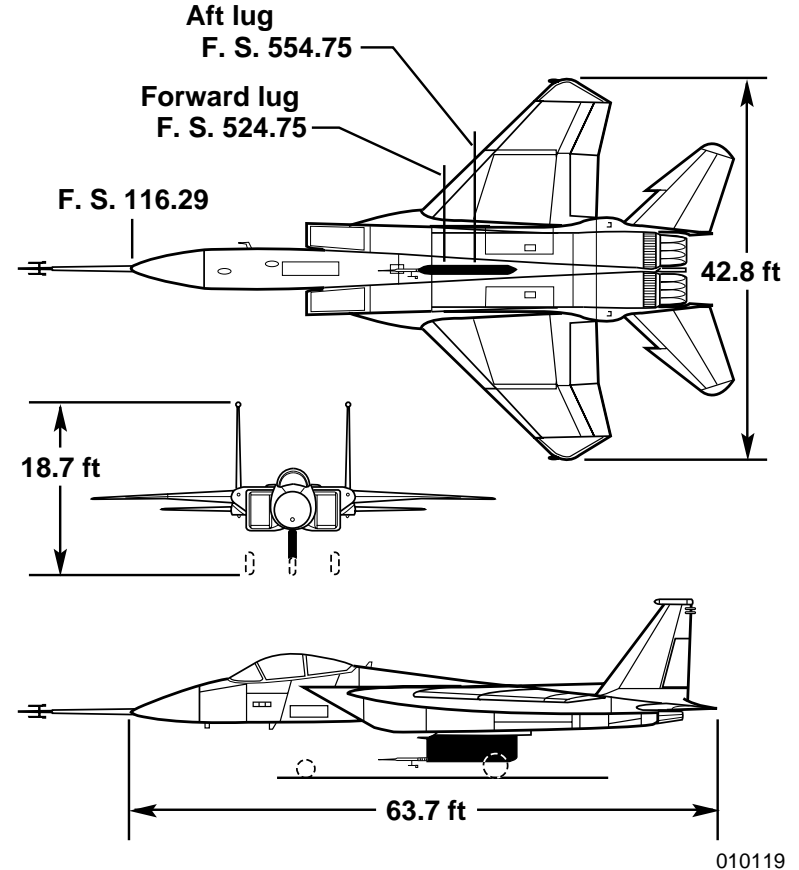

Figure 3. The NASA F-15B airplane with the FTF-II installed.

\section{PROPULSION FLIGHT TEST FIXTURE DESCRIPTION}

The PFTF is comprised of an aluminum main structure, an internal force balance, and internal equipment racks. The PFTF has a length of $107 \mathrm{in.}$ $(271.78 \mathrm{~cm})$, a height of $19 \mathrm{in} .(48.26 \mathrm{~cm})$, and a width of 10 in. $(25.40 \mathrm{~cm})$ (fig. 2). Fabricated from a solid billet of 6061-T6 aluminum, the empty PFTF main structure has a weight of approximately $350 \mathrm{lb}$ $(158.76 \mathrm{~kg})$. The PFTF internal configuration, experiment interface, and allowable experiment size are described in the following sections. A brief description of the expected aerodynamic flow quality around the PFTF is also given.

\section{Internal Configuration}

The PFTF is divided into three bays (forward, mid, and aft) that are separated by bulkheads and the force-balance structure. An equipment rack is installed in each bay for mounting experiment components such as instrumentation, propellant tanks, control boxes, and so forth. The nominal rack height is $15 \mathrm{in} .(38.10 \mathrm{~cm})$ and the internal bay height is $17.88 \mathrm{in}$. $(45.42 \mathrm{~cm})$. The volume above the racks can be used for routing instrumentation wiring. Table 1 shows the dimensions of each rack.
Table 1. Equipment rack data.

\begin{tabular}{lccc}
\hline \hline Rack & $\begin{array}{c}\text { Length, } \\
\text { in. }(\mathrm{cm})\end{array}$ & $\begin{array}{c}\text { Width, } \\
\text { in. }(\mathrm{cm})\end{array}$ & $\begin{array}{c}\text { Maximum } \\
\text { equipment } \\
\text { weight, } \\
\text { lb }(\mathrm{kg})\end{array}$ \\
\hline Forward & $15(38.1)$ & $\begin{array}{c}\text { Tapered from } 8 \text { to } 3 \\
(20.3-7.6)\end{array}$ & $100(45.4)$ \\
Mid & $21(53.3)$ & $8(20.3)$ & $200(90.7)$ \\
Aft & $33(83.8)$ & $8(20.3)$ & $200(90.7)$ \\
\hline \hline
\end{tabular}

The vertical position of the center shelf in each rack is adjustable. The racks and shelves are constructed of aluminum angle and plate and are easily removed through the bottom of the PFTF. The modular nature of the racks permits experiment integration independent of the PFTF structure. The racks are available for experiment use, but their use is not required. An experimenter may choose to fabricate specialized racks or mounting hardware that can be integrated with the PFTF.

Figure 4 shows the location of several PFTF internal components. Instrumentation and telemetry equipment currently occupy both sections of the forward bay and the upper section of the mid bay. This equipment comprises the standard PFTF instrumentation system to be used on all flights. Notional propulsion system tanks are shown in the other bays to illustrate a possible PFTF configuration.

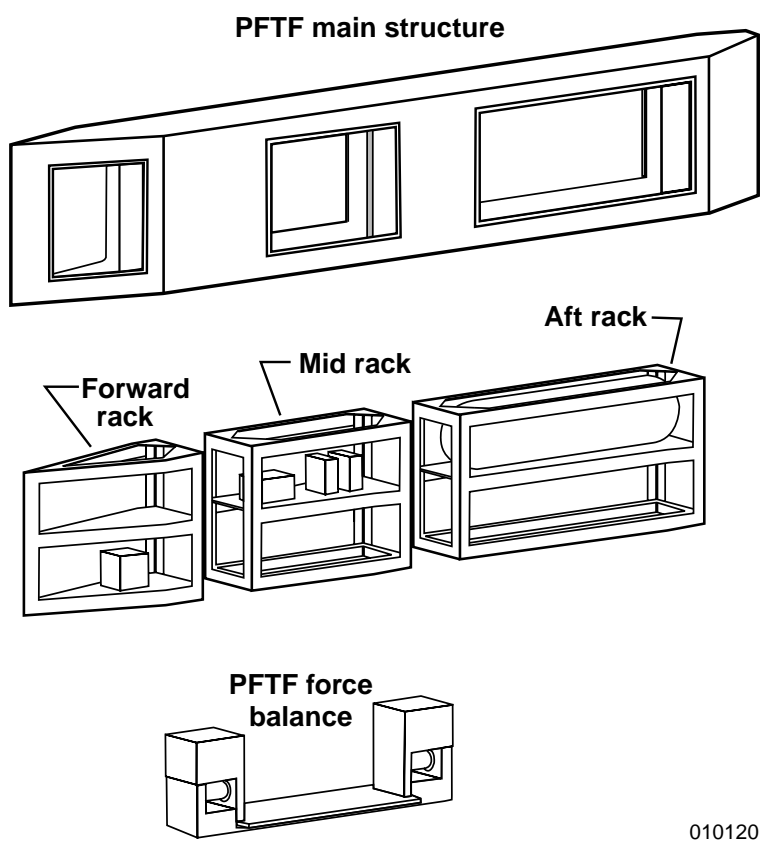

Figure 4. PFTF internal layout. 


\section{Experiment Interface}

Experiments will be mounted to the PFTF pylon using a flat, force-balance metric plate located below the middle rack. Figure 5 shows the metric and nonmetric details of the force balance. The bottom surface of the metric plate is parallel with the bottom of the PFTF and protrudes from the bottom by $1.0 \mathrm{in}$. $(2.54 \mathrm{~cm})$. Experiments will be mounted to the metric plate through eight, 3/8-24 helicoiled attachment points.
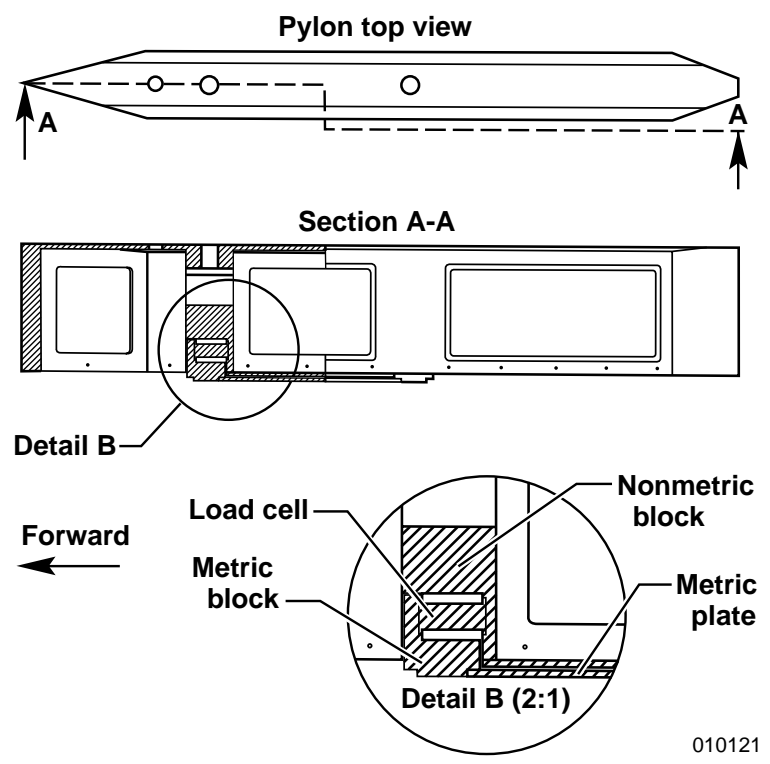

Figure 5. PFTF metric and nonmetric sections.

Care must be used in routing electrical and fluid connections across the metric break to not foul the force balance. Typically, the force balance will be zeroed again after all electrical lines are installed and fluid lines are pressurized. Force-balance characteristics are detailed in the "In-Flight Force Balance" section.

\section{Instrumentation System}

The PFTF instrumentation system is a subsystem of the F-15B system (fig. 6). The airplane uses a time division multiplexed system (TDMS) as the primary method of collecting sensor data. The main component of the airplane data acquisition system is the Aydin Vector (Newtown, Pennsylvania) model MMSC 800 encoder. This encoder can accept both analog and digital signal inputs and provides a pulse code modulation (PCM) output for transmission and onboard recording. Located on a pallet in the aircraft ammunition bay, the PCM system serves as a master control stack for remote
PCM system stacks that are located in other sections of the airplane or test fixture.

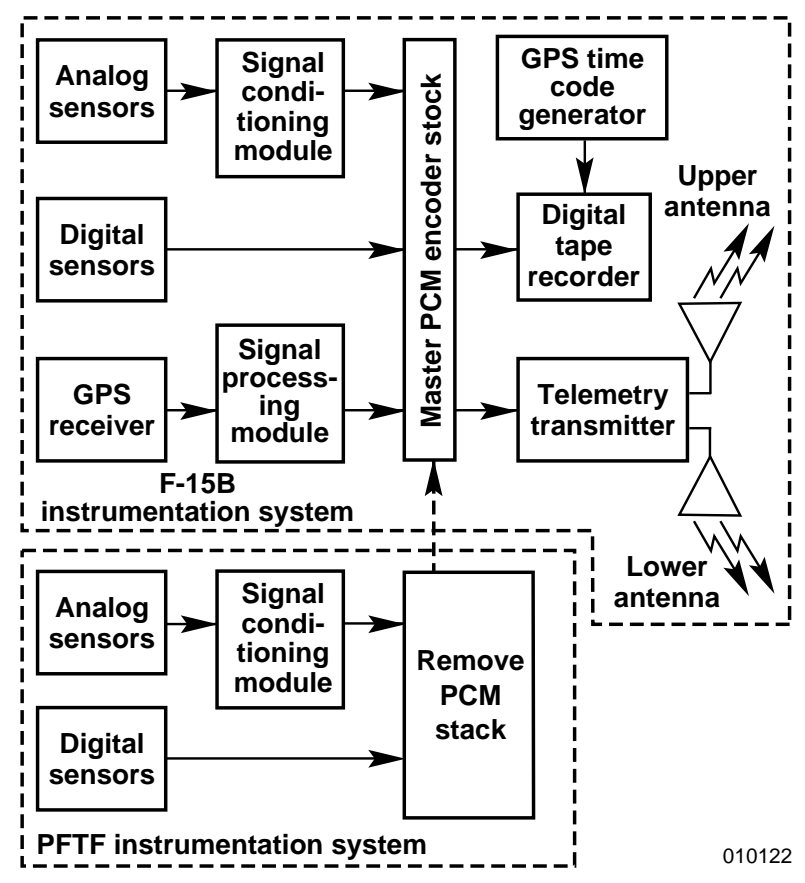

Figure 6. PFTF instrumentation system.

A remote PCM stack is located in the PFTF, along with analog signal-conditioning and digital signal interface modules. All PFTF sensors are processed by the remote PCM stack and merged with the aircraft data stream (fig. 6). The master PCM stack converts all analog signals to digital 12-bit words before serializing the bit stream for output. Analog and digital signal-conditioning interface modules and instrumentation power supplies are also located on the ammunition bay pallet.

The airplane telemetry system can simultaneously transmit two PCM bit streams using two S-band transmission frequencies. This feature allows for a second master PCM system to be added to the PFTF to accommodate high-frequency measurements. Both S-band telemetry transmitters can radiate $5 \mathrm{~W}$ of power. The power of each transmitter is equally divided to transmit through the upper and lower airplane antennas.

The airplane onboard recording system consists of a digital magnetic media recorder configured to record three PCM bit streams and IRIG-B time code. The recorder is capable of more than 8 hours of data recording. The recorded flight data is correlated with the IRIG-B time 
code that is generated by an onboard global positioning system (GPS) time code receiver/generator.

The baseline airplane measurement list consists of 40 analog parameters and 25 digital parameters. Available airplane measurements include noseboom static and total pressure, total temperature, three-axis linear accelerations, three-axis angular rates, noseboom angle of attack, angle of sideslip, and GPS data.

The baseline PFTF measurement list consists of 124 analog parameters. Available PFTF measurements include leading-edge static and total pressure, total temperature, three-axis linear accelerations, three-axis angular rates, experiment reference pressure, experiment differential pressures, and force-balance load cell measurements.

\section{$\underline{\text { In-Flight Force Balance }}$}

The PFTF incorporates a six-degree-of-freedom force balance that provides an in-flight force measurement capability (fig. 7). The force balance was designed, fabricated, and calibrated by Integrated AeroSystems (Costa Mesa, California). The balance was designed to satisfy several important requirements. First, the balance has to fit into a relatively small area between the bulkheads of the PFTF. Second, the balance must be able to accurately measure to the maximum design loads and not fail if stressed to three times these loads. Third, the force balance must be of operational flight quality, meaning that it must operate properly and reliably under the pressure, temperature, vibration, and loading environment of flight.

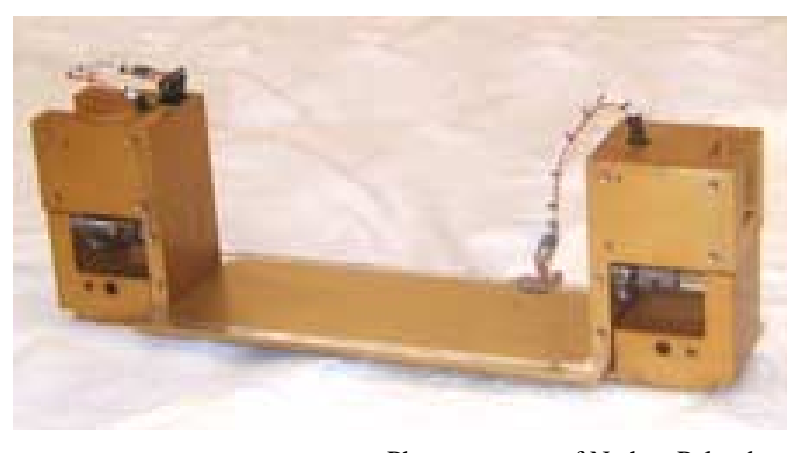

Photo courtesy of Nathan Palumbo.

Figure 7. PFTF force balance.

Table 2 shows the force-balance design and ultimate loads. The design loads in the axial $(x)$, side $(y)$, and vertical ( $z$ ) directions are 2000, 500, and $1500 \mathrm{lbf}$ (8896, 2224, and $6672 \mathrm{~N}$ ), respectively. The ultimate loads are three times the design limit loads. The design rolling, yawing, and pitching moments are \pm 8520 in-lb $(962.631 \mathrm{~N}-\mathrm{m}), \pm 10,080 \mathrm{in}-\mathrm{lb}(1138.887 \mathrm{~N}-\mathrm{m})$, and $\pm 55,080 \mathrm{in}-\mathrm{lb}(6223.204 \mathrm{~N}-\mathrm{m})$, respectively.

Measurements from ten strain gages in the force balance are used to compute the three forces and three moments. As a safety feature, the force balance incorporates overload bolts designed to retain the balance within the PFTF in the event of load cell failure. The metric side of the balance can be isolated with lockout pins if balance operation is not required in flight, or for protection of the balance (for example, during ground handling).

Table 2. Force-balance specifications.

\begin{tabular}{cccc}
\hline \hline Component & Design & Ultimate & $\begin{array}{c}\text { Predicted accuracy, } \\
\text { percent error of } \\
\text { measured value }\end{array}$ \\
\hline Axial force & $\pm 2,000 \mathrm{lbf}$ & $\pm 6,000 \mathrm{lbf}$ & $<0.5$ \\
Side force & $\pm 500 \mathrm{lbf}$ & $\pm 1,500 \mathrm{lbf}$ & $<1.0$ \\
Vertical force & $\pm 1,500 \mathrm{lbf}$ & $\pm 4,500 \mathrm{lbf}$ & $<2.0$ \\
Roll moment & $\pm 8,520 \mathrm{in}-\mathrm{lb}$ & $\pm 25,560 \mathrm{in}-\mathrm{lb}$ & $<5.0$ \\
Yaw moment & $\pm 10,080 \mathrm{in}-\mathrm{lb}$ & $\pm 30,240 \mathrm{in}-\mathrm{lb}$ & $<5.0$ \\
Pitch moment & $\pm 55,080 \mathrm{in}-\mathrm{lb}$ & $\pm 165,240 \mathrm{in}-\mathrm{lb}$ & $<5.0$ \\
\hline \hline
\end{tabular}


After construction, the force balance was calibrated to quantify the accuracy and cross-axis interactions. The balance accuracy is a function of the loading conditions; therefore, only approximate numbers are discussed that apply to the full envelope of the balance. Table 2 shows these approximate force-balance accuracies. The axial, side, and vertical force percent errors of measured value are less than $0.5,1.0$, and 2.0 percent, respectively.

\section{Experiment Size}

The overall size of the experiment that can be mounted on the PFTF is limited by the F-15B geometry. The experiment height is limited by the minimum acceptable ground clearance, which assumes a "worstcase" scenario of a main landing gear flat tire combined with a deflated main landing gear strut. The experiment width is limited to provide clearance between the aircraft main landing gear. The experiment length is governed by the experiment shape and mounting angle. The 13-deg rotation angle of the aircraft during a normal takeoff further limits the size of the aft section of an experiment. The approximate maximum experiment dimensions are a height of $21 \mathrm{in} .(53.34 \mathrm{~cm})$ and a width

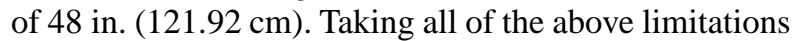
into account, the external experiment size envelope is as shown in figure 8 .

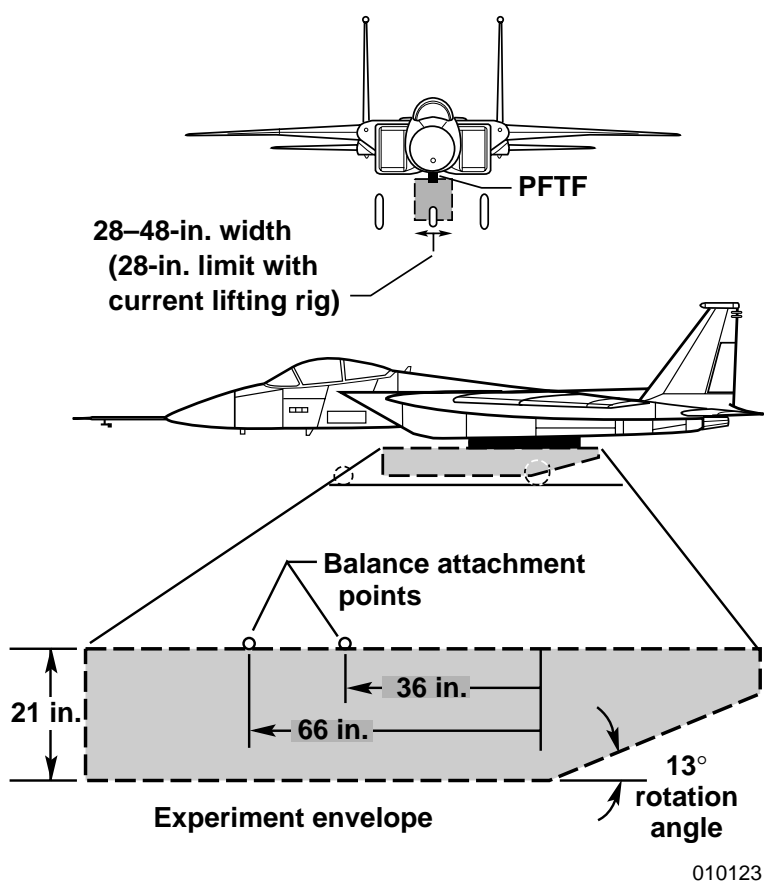

Figure 8. External experiment size.

Flow Quality

A large, qualitative flight database exists for the flow quality underneath the $\mathrm{F}-15 \mathrm{~B}$ airplane carrying the aerodynamic FTF-II. Although no efforts have been made to quantify the flow quality under the airplane, prior flow visualization experiments have shown the airflow to be relatively smooth and uniform. ${ }^{1}$

The data also show that an induced downwash exists underneath the airplane. Downwash data are available at the location where an inlet of a PFTF propulsion experiment might be placed. The local flow angle, with respect to the wing chord line, at this station was shown to vary in flight from approximately $1^{\circ}$ at Mach 0.4 to approximately $-9^{\circ}$ at Mach 2.0. Reference 1 provides further details regarding the downwash below the airplane. If local flow angle is critical, an experiment should be designed with the flexibility to adjust the mounting incidence angle to obtain the desired flow angle in flight at different Mach numbers.

\section{PROPULSION FLIGHT TEST FIXTURE DESIGN}

In designing the PFTF, analyses were performed in the areas of aerodynamics, stability and control, and static structural loads. The following sections provide details of these analyses and predictions.

\section{$\underline{\text { Aerodynamics }}$}

The PFTF aerodynamic analyses were performed to determine the drag, side force caused by angle of sideslip $(\beta)$, center of pressure, and aerodynamic loads caused by gusts. The demonstrated flight envelope for the FTF-II was used as a baseline for the desired flight envelope of the PFTF (fig. 9). The FTF-II was designed to meet a worst-case loading condition corresponding to sea-level flight at $800 \mathrm{kn}$; however, experience in flying the FTF-II has shown that a more realistic, operational airspeed limit is $650 \mathrm{kn}$. Therefore, a 650-kn airspeed limit was used in the PFTF aerodynamics calculations to a maximum of Mach 2. The sea-level, 650-kn flight

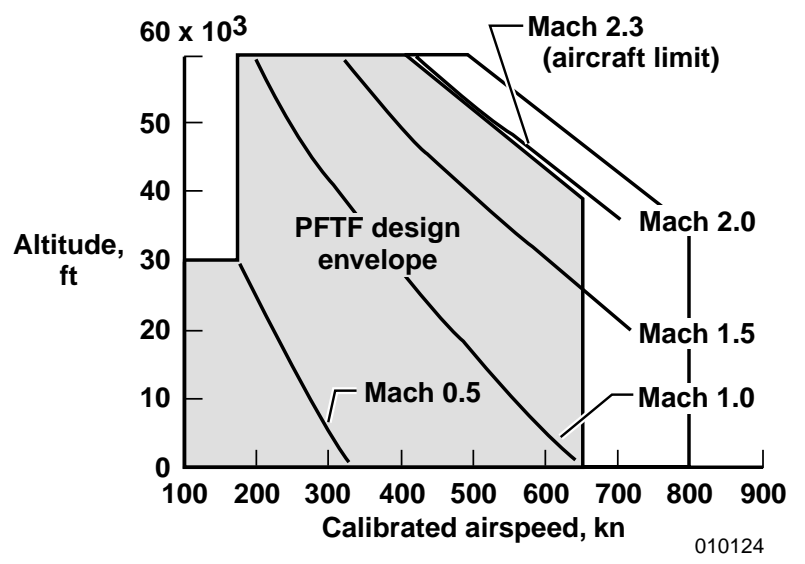

Figure 9. F-15B/PFTF flight envelope. 
condition results in a dynamic pressure of $1433 \mathrm{lbf} / \mathrm{ft}^{2}$ $(68.61 \mathrm{kPa})$.

\section{Aerodynamic Drag Model}

The PFTF geometry used in the aerodynamic analyses consisted of the basic PFTF structure and a representative propulsion experiment "tube" hung underneath the PFTF. The PFTF has a total leading-edge wedge angle of $31^{\circ}$ and a moderately tapered, squared base area. The modeled tube was 12 in. $(30.48 \mathrm{~cm})$ in diameter and $10 \mathrm{ft}(3.048 \mathrm{~m})$ in length.

The drag models for the PFTF and tube were empirically modeled using data from reference 2 . The drag model incorporated skin friction, wave, and base drag at $\beta=0^{\circ}$. The PFTF wave drag was calculated using data for a two-dimensional wedge with a constantthickness afterbody. The empirical data were a function of the body fineness ratio and Mach number. A two-dimensional base drag was calculated from data for a wedge-shaped airfoil with a blunt trailing edge. A threedimensional correction, based on the PFTF fineness ratio, was applied to the two-dimensional drag prediction. (The PFTF fineness ratio is defined as the maximum cross-sectional height divided by the maximum width.) The PFTF skin-friction drag was calculated based upon incompressible turbulent flow over a flat plate. ${ }^{3}$ This incompressible flow assumption is conservative because the compressibility reduces the value of the skin-friction coefficient.

The drag of a representative tube was predicted using two models: an open-nosed tube with zero internal flow (that is, a blocked duct), and a solid cylinder. For the blocked duct, additive (spillage) drag was estimated for a normal shock inlet. Internal and external skin-friction drag for the duct was also added. (Note that although the tube was assumed to be blocked, the internal skin-friction drag was included.) For the solid cylinder, simple empirical drag data were used. In both cases, the PFTF base drag coefficient was used in calculating the tube base drag. The reference area for the drag calculations was the combined cross-sectional area of the PFTF and tube. The solid cylinder model resulted in a higher predicted drag than the blocked duct; therefore, the solid cylinder drag was used in the PFTF loads calculations.

Figure 10 shows the predicted drag coefficient, $C_{D}$, as a function of Mach number for the PFTF and tube. The $C_{D}$ of the combined PFTF and solid cylinder is compared to the $C_{D}$ for bodies with various leading-edge angles and similar total heights. The $C_{D}$ for an aircraft centerline fuel tank, that has a modified Sears-Haack body shape, is also shown for comparison. The $C_{D}$ for the PFTF and solid cylinder is higher than for all of the comparison shapes throughout the Mach range. The PFTF and solid cylinder has a maximum $C_{D}$ of approximately 1.25 at Mach 1.0.

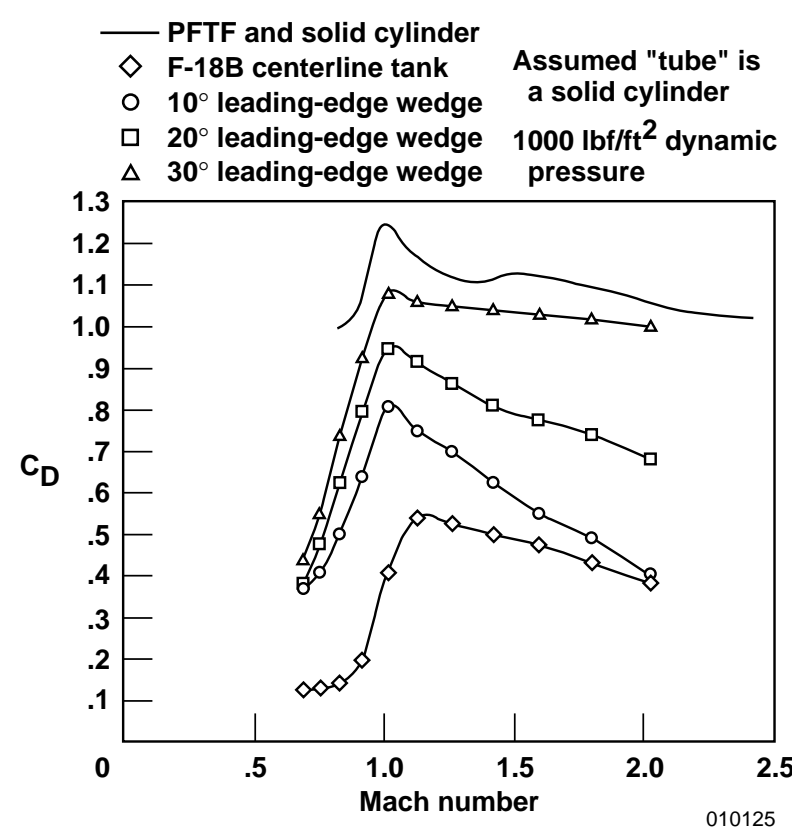

Figure 10. PFTF and solid cylinder $C_{D}$ as a function of Mach number.

\section{$\underline{\text { Side Force Caused by Angle of Sideslip }}$}

Aerodynamic side forces caused by $\beta$ were calculated for a maximum product of $\beta$ and dynamic pressure $(q)$ of $5500 \mathrm{deg} \cdot \mathrm{lbf} / \mathrm{ft}^{2}(263.341 \mathrm{kPa})$. This $\beta q$ limit is based on operational flight experience with the F-15B/FTF-II. The side force coefficient, $C_{Y}$, was calculated within the $\beta q$ limit for a maximum $\beta$ of $10^{\circ}$. This limit is based on the expected experiment $\beta$ requirements and the airplane $\beta$ capability in flight. The side force was estimated using a simple "sin $\beta$ " approximation in which $C_{Y}$ is set equal to the sine of $\beta$. The F-15B/FTF-II flight data ${ }^{1}$ have shown that this $\sin \beta$ approximation provides a conservative estimate of the side force caused by $\beta$.

The largest PFTF side forces were obtained for flight conditions at the lower right corner of the flight envelope $\left(650 \mathrm{kn}\right.$ at sea level and $q=1433 \mathrm{lbf} / \mathrm{ft}^{2}$ or $68.61 \mathrm{kPa})$. For this case, based on a $\beta q$ of $5500 \mathrm{deg} \cdot \mathrm{lbf} / \mathrm{ft}^{2}(263.341 \mathrm{kPa}), \beta=3.84^{\circ}$. The resultant side force, calculated using the $\sin \beta$ approximation, is 2210 lbf $(9830.57 \mathrm{~N})$. 


\section{Aerodynamic Gust Loads}

Aerodynamic loads on the PFTF caused by gusts were investigated. At normal flight speeds, the gust loads generally were not significant. The most critical flight condition for gust loads was at rotation speed for takeoff. At rotation speed, a gust generated the largest change in the relative $\beta$ and, therefore, the highest load. The F-15B aircraft rotates for takeoff at approximately $120 \mathrm{kn}(203 \mathrm{ft} / \mathrm{sec}$ or $61.87 \mathrm{~m} / \mathrm{sec})$, so this was the slowest speed at which gust loads were evaluated. The maximum possible gust factor used in the calculations was a velocity of $37 \mathrm{ft} / \mathrm{sec}(11.28 \mathrm{~m} / \mathrm{sec})$, based upon flight test experience.

For the 120-kn rotation speed, a $37-\mathrm{ft} / \mathrm{sec}$ $(11.28 \mathrm{~m} / \mathrm{sec})$ gust that impacts the PFTF broadside at an angle of $90^{\circ}$ to the free-stream direction results in a relative $\beta$ of approximately $10.4^{\circ}$. As discussed previously, a maximum $\beta$ of $10^{\circ}$ is a reasonable limit for PFTF flight operations. The maximum allowable PFTF side load caused by a gust at takeoff rotation was calculated to be $204 \mathrm{lbf}(907.4 \mathrm{~N})$. This gust load will not appreciably affect the aircraft controllability at takeoff.

\section{$\underline{\text { Center of Pressure }}$}

The center of pressure for the PFTF was not analytically or empirically determined. Typically, the center of pressure for lifting surfaces, such as wings, is located at approximately the quarter-chord point for subsonic flight and at the semichord point for supersonic flight. For the FTF-II, the center of pressure travel was estimated to be between 15- and 66-percent mean aerodynamic chord. Flight tests have shown the center of pressure for the FTF-II has not been farther back than approximately 50-percent chord. Based upon the FTF-II results, the center of pressure was estimated to travel between 15-and 50-percent chord and have a uniform pressure distribution along the vertical span of the fixture.

\section{$\underline{\text { Stability and Control }}$}

The PFTF is mounted near the F-15B center of gravity and is not expected to cause significant stability and control problems. Because the PFTF is mounted at the same location as the centerline-mounted external fuel tank, the configuration is expected to exhibit similar stability characteristics. To verify this assumption, a stability analysis was performed for a representative PFTF geometry. The assumed configuration consisted of the PFTF; a 4-ft (1.22-m) long, 10-in. (25.4-cm) diameter, experiment "tube" mounted underneath the PFTF; and an aerodynamic fairing between the tube and
PFTF. The tube had a 30-deg total-angle conical nosetip and a blunt base.

A three-dimensional model of the computational fluid dynamics (CFD) of the PFTF and tube was created for this configuration to determine aerodynamic forces generated by the PFTF under several flight conditions. The aircraft center of gravity used for the analysis was 28-percent mean aerodynamic chord, which corresponded to a fuselage station of 561.7. The computational grid was created using commercially available software, ${ }^{4}$ and the solution was obtained using the WIND finitevolume, Navier-Stokes CFD code. ${ }^{5}$

The computed surface pressures were integrated to obtain the aerodynamic forces. The forces were converted to aircraft stability derivative increments and added to F-15 air-superiority stability derivatives, which were used as the baseline configuration to obtain the complete F-15B/PFTF stability derivatives. The F-15 air-superiority derivatives were obtained from U. S. Air Force flight tests. ${ }^{6}$ The calculated F-15B/PFTF stability derivatives were incorporated into the NASA Dryden F-15 manned flight simulator to examine handling qualities.

\section{Longitudinal Stability}

In general, the PFTF and experiment drag will produce a nosedown pitching moment and tend to increase overall aircraft longitudinal stability. Figure 11 shows the predicted aircraft longitudinal static stability derivative, $C_{m_{\alpha}}$, as a function of Mach number. Data for the F-15 air-superiority configuration and the F-15 configuration that has an external, centerline fuel tank, as obtained from U. S. Air Force flight tests, ${ }^{6}$ are shown for comparison. The air-superiority configuration has four fuselage-mounted AIM 7-F Sparrow missiles (Raytheon Corporation, Lexington, Massachusetts) and no centerline fuel tank. In the available literature, this configuration is the closest to "clean." Transonic values are not shown because the baseline F-15 aircraft data were not available.

The PFTF configuration is predicted to have positive longitudinal static stability (negative $C_{m_{\alpha}}$ ) comparable to the current operational F-15 configurations. At subsonic and supersonic speeds, the PFTF is predicted to be more longitudinally stable than either the F-15 clean configuration or the F-15 configuration with the centerline tank. At speeds approaching Mach 1, the PFTF stability matches the other F-15 configurations. 


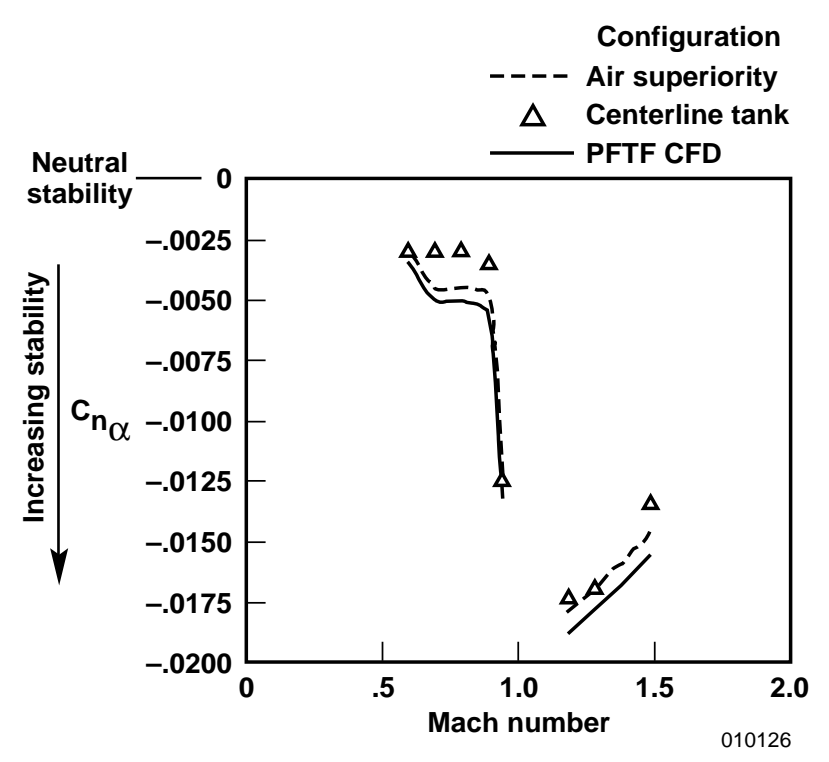

Figure 11. Aircraft static longitudinal stability derivatives.

\section{Lateral-Directional Stability}

Lateral and directional stability derivatives were obtained by the same method used to estimate longitudinal stability derivatives. The F-15/PFTF configuration was expected to exhibit similar lateral and directional stability characteristics as the F-15 centerline tank configuration; however, this was not the case for dihedral effect. Figure 12 shows the aircraft dihedral effect derivative, $C_{l_{\beta}}$, as a function of Mach number. The predicted PFTF ${ }^{\beta}$ dihedral effect is less than that of the F-15 centerline tank configuration, and the U. S. Air Force flight tests demonstrate a stabilizing effect caused by the centerline fuel tank mounted at the same location. Although the PFTF configuration exhibits reduced $C_{l_{\beta}}$ compared to the F-15 clean configuration, the increment does not significantly reduce dihedral effect.

Aircraft directional stability was of some concern. In the supersonic flight regime, the F-15 aircraft rapidly becomes less directionally stable. Figure 13, in which the directional static stability derivative, $C_{n_{\beta}}$, is plotted as a function of Mach number, shows this characteristic. Predicted directional stability derivatives for the F-15/PFTF configuration show good agreement with the centerline tank configuration. As expected, static directional stability decreases with increasing Mach number and reaches $C_{n_{\beta}}$ values as low as 0.0005 , but remains stable $\left(C_{n_{\beta}}\right.$ positive).

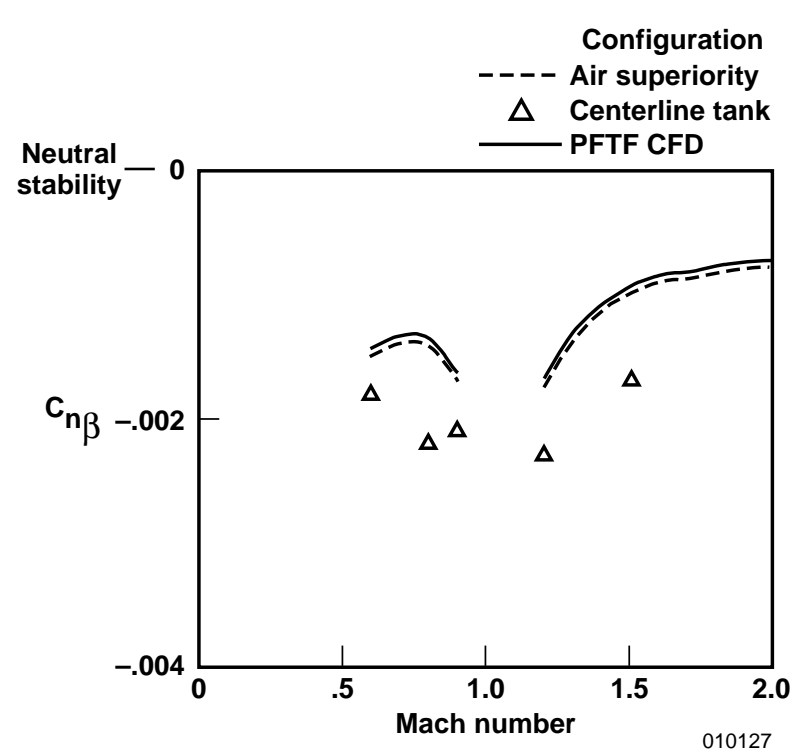

Figure 12. Aircraft dihedral effect derivatives.

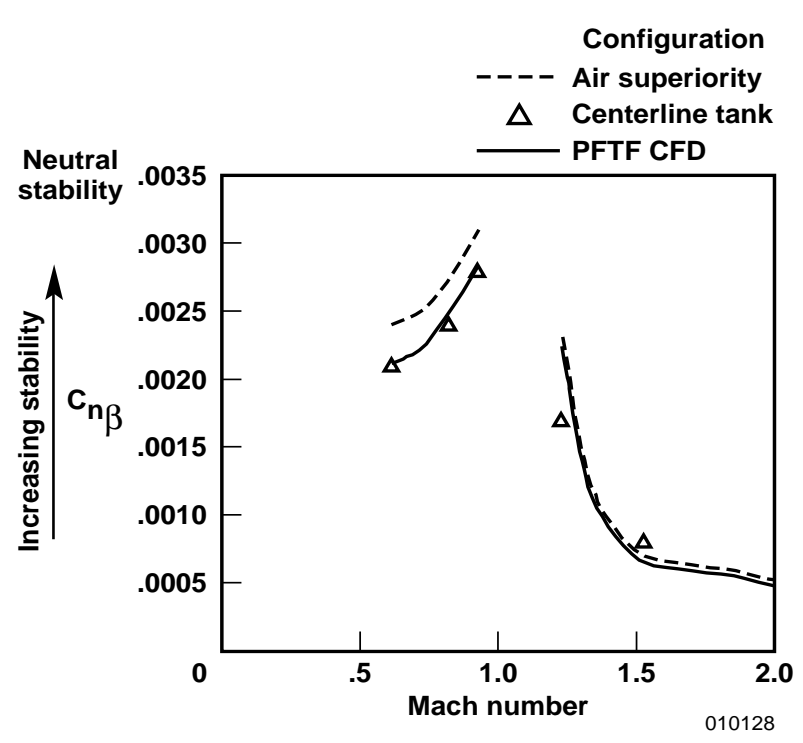

Figure 13. Aircraft static directional stability derivatives.

\section{Flight Simulation Testing and Capabilities}

The calculated PFTF stability derivative increments were incorporated into the NASA Dryden F-15 manned flight simulator to further evaluate F-15B/PFTF stability and control. A lookup table, consisting of stability derivative increments, was created and incorporated into the simulation. The F-15B/PFTF stability and control was investigated by evaluating aircraft controllability and response to large $\beta$ inputs at 
various flight conditions. The simulation demonstrated that the PFTF had almost no effect on the aircraft flying qualities. The simulation can be easily modified to simulate future propulsion experiments by modifying the stability derivative database.

\section{$\underline{\text { Loads and Stress Analysis }}$}

The PFTF was structurally designed to fit within the established flight envelope of the F-15 configuration with the external, centerline fuel tank. Airframe loading limits developed for this F-15 configuration were used as the maximum allowable for the PFTF. For an F-15 centerline store, two centerline suspension lugs carry the vertical loads and four sway braces carry the lateral loads.

Inertial loads were calculated for $7.5-g$ vertical and 1.5- $g$ lateral accelerations, assuming a combined PFTF and experiment maximum weight of $1600 \mathrm{lb}$ $(725.75 \mathrm{~kg})$. The F-15 operational flight requirements necessitate that the PFTF center of gravity remain between the suspension lug locations where the PFTF attaches to the airplane. This requirement constrains the PFTF center-of-gravity limits to between 26 and 54 percent of the PFTF 107-in. (271.78-cm) chord length. The propulsion experiment center of gravity must also remain between the forward and aft suspension lug locations. This requirement is satisfied as long as the experiment center of gravity is between the forward and aft force-balance attachment points.

Shear and bending analyses assumed that the airplane suspension lugs and sway braces are statically determinate where shear loads are supported by the suspension lugs and lateral moment loads are distributed to the leeward forward and leeward aft sway pads. The PFTF internal loads were conservatively calculated assuming the center of pressure was between 15- and 50percent chord and the center of gravity was between 26and 54-percent chord. For center-of-pressure or center-ofgravity locations of 15 - or 33-percent chord, 60 percent of the lateral moments were applied to the forward suspension lug. For a center of pressure of 50-percent chord, the lateral moments were shared equally between the forward and aft lugs. The vertical distribution of all loads was assumed to be uniform.

In calculating the moments about the lateral axis caused by inertial forces, the entire moment was assumed to be carried by a single suspension lug nearest to the force. The worst-case moments generated on the lugs by the weight of the PFTF were derived in this manner. Axial loads were evaluated assuming that all of the loads were absorbed by the front lug or aft lug only.

Ten load cases were evaluated in various combinations: three related to aerodynamic side loads applied at 15- and 50-percent chord for a $\beta q$ of $5500 \mathrm{deg} \cdot \mathrm{lbf} / \mathrm{ft}^{2}(263.341 \mathrm{kPa})$; two related to inertial side loads at $1.5 \mathrm{~g}$ applied at 26- and 54-percent chord; two related to inertial vertical loads at $7.5 \mathrm{~g}$ applied at 26- and 54-percent chord; two related to axial loads on the forward-aft lug; and one related to the lug preloads caused by preloads on the sway braces (table 3 ). The aerodynamic side load and inertial loading cases were

Table 3. Summary of PFTF applied loads.

\begin{tabular}{|c|c|c|c|}
\hline Applied load & $\begin{array}{c}F_{x}, \\
\operatorname{lbf}(\text { positive } x \text { aft) }\end{array}$ & $\begin{array}{c}F_{y}, \\
\text { lbf (positive } y \text { right) }\end{array}$ & $\begin{array}{c}F_{z} \\
\text { lbf (positive } z \text { up) }\end{array}$ \\
\hline \multicolumn{4}{|l|}{ Aerodynamic loads: } \\
\hline$q=1000 \mathrm{lbf} / \mathrm{ft}^{2}\left(\beta=0^{\circ}\right)$ & 2247 & 0 & 0 \\
\hline$q=1092 \mathrm{lbf} / \mathrm{ft}^{2}\left(\beta=0^{\circ}\right)$ & 2454 & 0 & 0 \\
\hline$q=1432.5 \mathrm{lbf} / \mathrm{ft}^{2}\left(\beta=0^{\circ}\right)$ & 3340 & 0 & 0 \\
\hline$\beta q=5500\left(q=1432.5 \mathrm{lbf} / \mathrm{ft}^{2}\right)$ & 3340 & 2210 & 0 \\
\hline$\beta q=5500\left(q=1092 \mathrm{lbf} / \mathrm{ft}^{2}\right)$ & 2454 & 1685 & 0 \\
\hline$\beta q=5500\left(q=550 \mathrm{lbf} / \mathrm{ft}^{2}\right)$ & 1236 & 2200 & 0 \\
\hline \multicolumn{4}{|l|}{ Inertial loads: } \\
\hline $7.5 \mathrm{~g}$ normal & 0 & 0 & -12000 \\
\hline $1.5 \mathrm{~g}$ axial & 2400 & 0 & -1600 \\
\hline $1.5 \mathrm{~g}$ lateral & 0 & 2400 & -1600 \\
\hline Vertical preload (at fore and aft lugs) & 0 & 0 & -3024 \\
\hline
\end{tabular}


evaluated using a waterline moment arm of $15.5 \mathrm{in}$. $(39.37 \mathrm{~cm})$ as the loads were transferred into the airplane suspension lugs and sway braces. The aerodynamic axial load cases used a moment arm of 16.5 in. $(41.91 \mathrm{~cm})$ as the loading was transferred directly into the airframe. The resulting shear and moment diagrams, required for seven of the load cases, were analyzed and cleared as having no impact to the airplane.

Based on the above assumptions, a thorough stress analysis of each fixture structural component was performed using worst-case design limit shear or moment loads, as appropriate. The analyses included the PFTF, force balance, experiment adapter, suspension lug inserts, pylon internal racks and mounting hardware, and pylon side panels and mounting hardware. The minimum acceptable number of fasteners in each area was determined. The areas of most concern were the lower limbs of the aft section of the PFTF, which help support the large, cantilevered aft section and the heaviest internal rack.

The stress analyses determined that all margins of safety were positive. Margin of safety (MS) is defined as

$$
\mathrm{MS}=\frac{\text { Ultimate load or stress }}{(2.25)(\text { Design limit load or stress })}-1
$$

The lowest margin of safety calculated for the PFTF was 0.19 because of tearout stress in the internal racks when fully loaded to $200 \mathrm{lb}(90.7 \mathrm{~kg})$ and subjected to a $7.5-\mathrm{g}$ inertial load.

\section{Loads on the F-15 Centerline Pylon}

A conservative estimate of the loads transferred to the airplane pylon is to evaluate the combined aerodynamic and inertial loading in the longitudinal direction in summation with the highest loading along the vertical and lateral-directional axes of the airplane. In such an analysis, all the possible worst-case forces would simultaneously act upon the pylon. However, this summation does not reflect realistic scenarios. Under extreme flight conditions, only two of the three worst-case forces can couple at the same time.

Consequently, the maximum estimated loads at the horizontal centers of gravity and pressure of the PFTF are $F_{z}=-12,000 \mathrm{lbf}(-53,378.6 \mathrm{~N})$ (down), $F_{y}=2210 \mathrm{lbf}$ $(9830.6 \mathrm{~N})$ (right), and $F_{x}=3340 \mathrm{lbf}(14,857.1 \mathrm{~N})(\mathrm{aft})$ for the case in which the horizontal center of gravity is located 15.5 in. $(39.37 \mathrm{~cm})$ below the suspension lugs and sway braces on the pylon. Note that the side and axial forces, $F_{y}$ and $F_{x}$, do not include any inertial terms. An effective moment arm of $16.5 \mathrm{in}$. (41.91 cm)-1-in. $(2.54-\mathrm{cm})$ longer-was used to approximate the added height caused by the suspension lug.

These forces are relatively low when compared with the ultimate loads for the F-15 aircraft shown in table 4. The numbered conditions denote worst-case loading conditions defined within a large matrix used for the development of the FTF-II. ${ }^{1}$ To have confidence in the design of the PFTF, the ultimate loads on the fixture must not simply be less than each individual maximum

Table 4. F-15 cleared ultimate loads.

\begin{tabular}{|c|c|c|c|c|c|c|}
\hline $\begin{array}{l}\text { F-15 } \\
\text { configuration }\end{array}$ & Condition & $\begin{array}{c}F_{z}, \text { lbf } \\
\text { (up) }\end{array}$ & $\begin{array}{c}F_{y}, \text { lbf } \\
(\text { left })\end{array}$ & $\begin{array}{c}F_{x}, \text { lbf } \\
(\text { aft })\end{array}$ & $\begin{array}{l}\text { Moment } \\
\text { arm, in. }\end{array}$ & Comments \\
\hline Centerline tank & $\begin{array}{l}\text { \#24 rolling } \\
\text { pullout }\end{array}$ & $-34,400$ & -490 & 720 & 15.75 & $\begin{array}{c}\text { Maximum } \\
F_{z} \text { case }\end{array}$ \\
\hline Centerline tank & $\begin{array}{l}\text { \#26 rolling } \\
\text { pullout }\end{array}$ & $-29,200$ & 14,300 & 1,380 & “ & $\begin{array}{c}\text { Maximum } \\
F_{y} \text { case }\end{array}$ \\
\hline Centerline tank & $\begin{array}{c}\text { \#43 rolling } \\
\text { pullout }\end{array}$ & $-30,200$ & 12,020 & 7,250 & “ & $\begin{array}{c}\text { Maximum } \\
\text { combined } \\
\text { three-axis case }\end{array}$ \\
\hline Centerline tank & 9- $g$ crash & $-6,420$ & 0 & $-38,500$ & “ & $\begin{array}{c}\text { Maximum } \\
F_{x} \text { case }\end{array}$ \\
\hline PFTF totals & $\begin{array}{l}\text { Maximum } \\
\text { combination }\end{array}$ & $-27,000$ & 4,973 & 7,243 & 15.50 & $\begin{array}{c}\text { Maximum } \\
\text { combined } \\
\text { three-axis case }\end{array}$ \\
\hline
\end{tabular}


on the F-15 configuration that has the centerline tank. Rather, the ultimate loads on the PFTF must be less than those incurred by the F-15 airplane for a maximum combined three-axis loads case. Recall that the aerodynamic and inertial loading cases were evaluated using a moment arm of 15.5 in. $(39.37 \mathrm{~cm})$ as the loads were transferred into the sway braces. The dynamic pressure cases use a moment arm of 16.5 in. $(41.91 \mathrm{~cm})$ as the loading is transferred directly into the airframe.

\section{PLANNED FLIGHT EXPERIMENTS}

Planned PFTF flight experiments are described to provide insight about experiment design and PFTF flight test. The PFTF envelope expansion flights; flight tests of a simple, normal shock inlet configuration; and the RBCC flight experiment are discussed.

\section{Envelope Expansion Flights}

The PFTF envelope expansion flights will be performed to determine the performance envelope of the F-15B/PFTF configuration and verify acceptable flying qualities. These flights will clear the PFTF for flight in the design envelope while carrying a large test article. Also, the operations of the in-flight force balance and instrumentation system will be verified.

The PFTF will be flown with a large tube attached to simulate a propulsion experiment (fig. 14). The tube is $10 \mathrm{ft}(3.048 \mathrm{~m})$ in length and has a diameter of $10 \mathrm{in}$. $(25.4 \mathrm{~cm})$. The tube has a conical nose section and a blunt base. A five-hole conical probe extends from the conical nose to measure total pressure, angle of attack, and angle of sideslip. Static-pressure taps on the tube base measure the tube base pressure. The cone-tube

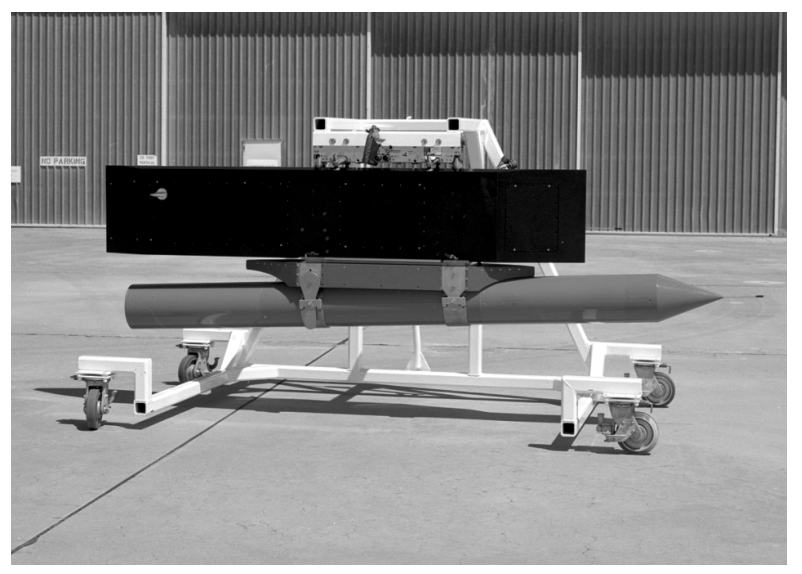

EC 01 109-05

Figure 14. Tube experiment. configuration is designed to create significant drag to help verify the operation of the in-flight force balance.

\section{$\underline{\text { Normal Shock Inlet Flight Tests }}$}

The next series of flight tests will use the PFTF with the same tube hardware flown in the envelope expansion flights. The cone nose and base plate will be removed from the tube to permit internal flow through the tube. A simple, normal shock inlet will be attached to the tube. The total pressure distribution will be mapped downstream of the inlet with a "wagon-wheel" type of flow distortion rake (fig. 15). These series of inlet flow tests will help characterize the flow for future propulsion experiments that will build on the tube hardware.

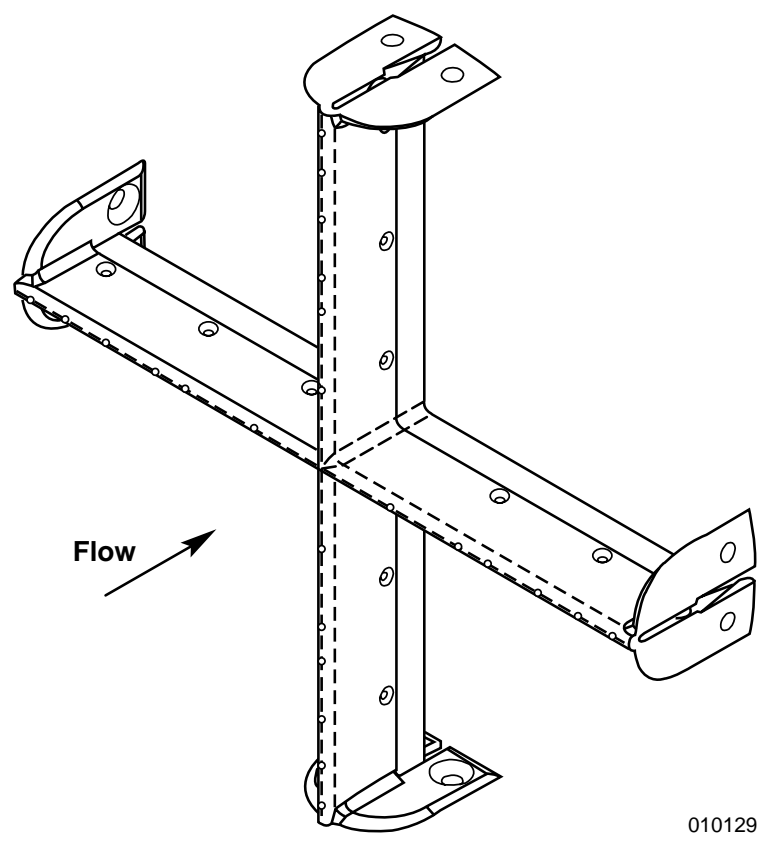

Figure 15. Inlet distortion rake.

\section{Rocket-Based Combined Cycle Experiment}

The first combusting propulsion test to be flown on the PFTF will be an axisymmetric, simultaneousmixing-and-combusting RBCC experiment (fig. 16). In this RBCC concept, a rocket is placed inside an airbreathing duct, allowing a fuel-rich, rocket exhaust to mix with the air inside the duct. ${ }^{7}$ The entrainment of air by the rocket exhaust and the burning of the fuel-rich exhaust augments the thrust of the rocket, thereby producing more thrust than does the rocket alone. 


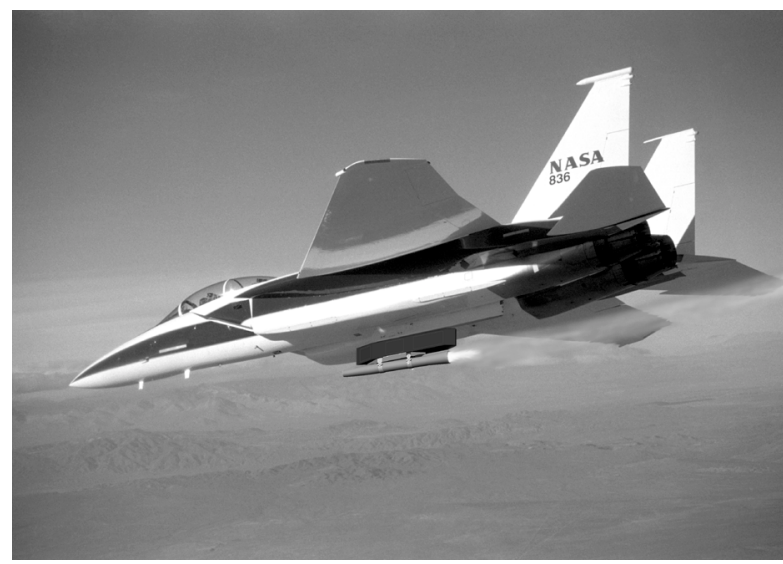

ED 01 0123-01

Figure 16. Conceptual RBCC experiment on F-15B/PFTF.

The RBCC flight experiment also will use the tube and normal shock inlet. A simple rocket thruster will be installed inside the tube. The rocket will be fueled with gaseous oxygen and methane. The maximum predicted RBCC thrust is approximately 1000 lbf (4448.2 N). The RBCC flight experiment will provide baseline flight data for comparison to design codes and analytical techniques for RBCC engines. The RBCC flight data will also be obtained at transonic Mach numbers for which obtaining wind-tunnel data is often difficult. Beyond the specific RBCC propulsion research goals, the experiment will serve to validate the PFTF capability to serve as a facility for future, more complex propulsion experiments.

\section{CONCLUDING REMARKS}

The Propulsion Flight Test Fixture (PFTF) offers a unique, low-cost flight research capability, available to the propulsion community, for the testing of propulsion systems and components in a real flight environment. The F-15B/PFTF combination has been predicted to provide flight test Mach numbers as great as Mach 1.8, altitudes to approximately $50,000 \mathrm{ft}(15,240 \mathrm{~m})$, and dynamic pressures as great as $1100 \mathrm{lbf} / \mathrm{ft}^{2}(52.67 \mathrm{kPa})$. Maximum propulsion experiment weights of approximately $500 \mathrm{lb}(226.8 \mathrm{~kg})$ can be flown. The F-15B/PFTF flight envelope makes the PFTF an ideal facility for testing propulsion systems that are applicable to aircraft and access-to-space vehicles in the subsonic, transonic, and low supersonic regions.

The aerodynamic Flight Test Fixture II (FTF-II) was discussed to highlight past experience leading to the development of the PFTF. A complete description of the
PFTF characteristics, capabilities, design, and planned experiments was provided.

Information was provided about the NASA F-15B carrier airplane and the installation of the PFTF. The size, capability, and construction of the PFTF were described. The PFTF geometry, internal configuration and capacity, and force balance system were discussed. The force balance can measure forces and moments in three axes and has a thrust measuring capability to a maximum of $2000 \mathrm{lbf}(8896.4 \mathrm{~N})$, with a predicted error below 0.5 percent. The instrumentation system design, capabilities, and measurement potential were given. The instrumentation system can monitor 124 PFTF measurements and telemeter the data to a ground station in real time.

The design of the PFTF was shown. Detail of the aerodynamic design, stability and control analysis, and structural design has been provided. The design proved to be conservative with large safety margins.

Finally, planned experiments for the PFTF were discussed. The first PFTF flight experiment will be a simple tube with a conical nosetip for use in envelope expansion and instrumentation checkout. Future propulsion-related experiments include inlet testing, distortion rake development, and firing of a methaneoxygen, axisymmetric, rocket-based combined cycle experiment.

\section{REFERENCES}

${ }^{1}$ Richwine, David M., F-15B/Flight Test Fixture II: A Test Bed for Flight Research, NASA TM-4782, 1996.

${ }^{2}$ Hoerner, Sighard F., Fluid-Dynamic Drag: Practical Information on Aerodynamic Drag and Hydrodynamic Resistance, Self-published work, Library of Congress Card Number 64-19666, Washington, D.C., 1965.

${ }^{3}$ Anderson, John D., Jr., Fundamentals of Aerodynamics, 2nd ed., McGraw-Hill, New York, 1991.

${ }^{4}$ Adaptive Research, CFD 2000: Computational Fluid Dynamics System Version 3.11 User's Manual, PacificSierra Research Corporation, 1998.

${ }^{5}$ Bush, R. H., G. D. Power, C. E. Towne, "WIND: The Production Flow Solver of the NPARC Alliance," AIAA-98-0935, Jan. 1998.

${ }^{6}$ Tanaka, Arthur Y. and Rodrigo J. Huete, F/TF-15A Flying Qualities Air Force Development Test and Evaluation, AFFTC-TR-76-48, July 1977.

${ }^{7}$ Heiser, William H. and David T. Pratt, Hypersonic Airbreathing Propulsion, American Institute of Aeronautics and Astronautics, Washington, D. C., 1994. 
Public reporting burden for this collection of information is estimated to average 1 hour per response, including the time for reviewing instructions, searching existing data sources, gathering and maintaining the data needed, and completing and reviewing the collection of information. Send comments regarding this burden estimate or any other aspect of this collection of information, including suggestions for reducing this burden, to Washington Headquarters Services, Directorate for Information Operations and Reports, 1215 Jefferson Davis Highway, Suite 1204, Arlington, VA 22202-4302, and to the Office of Management and Budget, Paperwork Reduction Project (0704-0188), Washington, DC 20503.

1. AGENCY USE ONLY (Leave blank)

2. REPORT DATE July 2001

\section{REPORT TYPE AND DATES COVERED}

Technical Memorandum

4. TITLE AND SUBTITLE

The F-15B Propulsion Flight Test Fixture: A New Flight Facility For

Propulsion Research

6. AUTHOR(S)

WU 529-35-14-00-38-00-F-15

Stephen Corda, M. Jake Vachon, Nathan Palumbo,

Corey Diebler, Ting Tseng, Anthony Ginn, and David Richwine

7. PERFORMING ORGANIZATION NAME(S) AND ADDRESS(ES)

NASA Dryden Flight Research Center

P.O. Box 273

Edwards, California 93523-0273

5. FUNDING NUMBERS

9. SPONSORING/MONITORING AGENCY NAME(S) AND ADDRESS(ES)

10. SPONSORING/MONITORING

AGENCY REPORT NUMBER

National Aeronautics and Space Administration

Washington, DC 20546-0001

NASA/TM-2001-210395

11. SUPPLEMENTARY NOTES

Presented at the 37th AIAA/SAE/ASME/ASEE Joint Propulsion Conference \& Exhibit, July 8-11, 2001,

Salt Lake City, Utah, AIAA 2001-3303.

\begin{tabular}{|l|l|l|l|l|}
\hline 12a. DISTRIBUTION/AVAILABILITY STATEMENT & DISTRIBUTION CODE
\end{tabular}

Unclassified-Unlimited

Subject Category 07

This report is available at http://www.dfrc.nasa.gov/DTRS/

13. ABSTRACT (Maximum 200 words)

The design and development of the F-15B Propulsion Flight Test Fixture (PFTF), a new facility for propulsion flight research, is described. Mounted underneath an F-15B fuselage, the PFTF provides volume for experiment systems and attachment points for propulsion devices. A unique feature of the PFTF is the incorporation of a six-degree-of-freedom force balance. Three-axis forces and moments can be measured in flight for experiments mounted to the force balance. The NASA F-15B airplane is described, including its performance and capabilities as a research test bed aircraft. The detailed description of the PFTF includes the geometry, internal layout and volume, force-balance operation, available instrumentation, and allowable experiment size and weight. The aerodynamic, stability and control, and structural designs of the PFTF are discussed, including results from aerodynamic computational fluid dynamic calculations and structural analyses. Details of current and future propulsion flight experiments are discussed. Information about the integration of propulsion flight experiments is provided for the potential PFTF user.

14. SUBJECT TERMS

F-15B flight testing, In-flight force balance, Propulsion flight test fixture, Propulsion flight testing, Rocket-based combined cycle propulsion
15. NUMBER OF PAGES

18

16. PRICE CODE

\begin{tabular}{|l|l|}
\hline $\begin{array}{l}\text { 17. SECURITY CLASSIFICATION } \\
\text { OF REPORT }\end{array}$ & $\begin{array}{l}\text { 18. SECURITY CLASSIFICATION } \\
\text { OF THIS PAGE } \\
\text { Unclassified }\end{array}$ \\
& Unclassified \\
\hline
\end{tabular}

NSN 7540-01-280-5500

19. SECURITY CLASSIFICATION
OF ABSTRACT
Unclassified

Unclassified
20. LIMITATION OF ABSTRACT

Unlimited 